\title{
基于遥感的煤炭型矿业城市土地利用与 生态承载力时空变化分析
}

\author{
顾康康 ${ }^{*}$ ，储金龙，汪勇政 \\ (安徽建筑大学建筑与规划学院, 合肥 230022 )
}

\begin{abstract}
摘要:运用遥感和社会经济系统发展指数修正生态足迹模型,开展淮南市土地利用与生态承载力时空演化分析。结果表明: 1987-2012 年, 淮南市人均生态承载力总体呈现缓慢降低后略微升高的趋势, 2009 年是人均生态承载力提升的拐点, 表明经济 科技因子的提升作用; 淮南市生态承载力时空差异显著,总体呈现东南和北部高、西部低的格局,而且区域破碎化加剧的趋势。 矿区占用大量耕地以及积水塌陷区的形成,是生态承载力的下降和空间格局分异的主要原因; 土地利用转移以耕地、建筑用地 为主, 水域对土地利用格局的影响日益增强,开展塌陷区整治,将塌陷区形成的水域转换成耕地或建设用地,将是提高淮南市生 态承载力的最有效途径之一。
\end{abstract}

关键词:生态足迹;经济系统发展指数;土地利用;塌陷区;淮南市

\section{Spatio-temporal analysis of land use and ecological carrying capacity in coal mining city based on remote sensing}

\author{
GU Kangkang* , CHU Jinlong, WANG Yongzheng \\ School of Architecture \& Planning, Anhui Jianzhu University, Hefei 230022, China
}

\begin{abstract}
We analyzed the spatio-temporal dynamics of land use and ecological carrying capacity in Huainan city with an improved ecological footprint model based on remote sensing and a social-economical system development index. The results showed that: from 1987 to 2012 , the ecological carrying capacity per capita educed gradually in the beginning and then increased slowly with 2009 being the inflection point, which reflected the positive effects of new economic development mode and science technology; The ecological carrying capacity in Huainan exhibited strong spatio-temporal variability with an overal spatial pattern of high capacity in Southeast and North and low in West and an increasing fragmentation trend at the regional scale. The loss of farmland to mining sites and the formation of seeper collapse area were the main causes of capacity decline and spatio-temporal variability. The main types of land use transfer were farmland and building land, and water area increasingly exerted great influences on land use pattern. Our study suggests that one of the most effective ways for improving ecological carrying capacity in Huainan is to conduct comprehensive treatment in the collapse areas, such as changing seeper collapse area into farmland and building land.
\end{abstract}

Key Words : ecological footprint; social-economical system development index; land use; collapse area; Huainan city

基金项目: 国家自然科学基金项目(41101566); 国家科技支撑计划课题(2012BAJ08B01-1)

收稿日期:2013-11-06; 修订日期:2014-08-04

*通讯作者 Corresponding author.E-mail: kangkanggu@163.com 
矿业城市是指因矿产资源开发而形成或发展起 来, 其主要功能或重要功能为向社会提供矿产品及 其初加工产品的一类城市 ${ }^{[1]}$ 。然而, 矿业城市在我 国经济发展过程中发挥重要作用的同时,也面临着 经济效益差、生态环境恶化等问题 ${ }^{[2]}$ 。众多研究表 明, 矿业城市问题的实质是社会经济活动强度超过 资源环境的承载能力 ${ }^{[3-5]}$ 。因此, 矿业城市生态承载 力研究已成为矿业城市生态经济可持续发展的热 点。目前, 加拿大学者 Mathis Wackernagel 提出的生 态足迹模型已成为国内外应用较广的生态承载力计 算方法 ${ }^{[6-9]}$,但该方法多以行政区划的土地利用统计 数据计算生态承载力, 存在土地利用统计数据尺度 较粗、时间滞后等弊端 ${ }^{[10-11]}$ 。此外,一个地区的生态 承载力不仅取决于当地的资源状况, 还与其经济发 展水平、科技水平有着很大的联系 ${ }^{[12]}$ 。因此, 利用 高分辨率遥感影像获取土地利用信息,通过经济、科 技因子对生态足迹模型修正, 对生态承载力评价方 法研究具有重要意义。本文以煤炭型矿业城市淮南 市为例, 选取该地区 1987 年、2000 年、2009 年和 2012 年 4 期遥感影像, 基于遥感解译和 GIS 空间分 析,探讨淮南市 1987-2012 年生态承载力时空变化 特征, 揭示生态承载力主要驱动因子, 提出生态承载 力提升途径, 研究结果可为淮南市生态格局优化和 可持续发展提供科学依据。

\section{1 研究区域与方法}

\section{1 研究区域}

淮南市位于长江三角洲腹地, 安徽省中北部, 淮 河之滨, 1950 年依矿建市, 全市总面积 2596.4 平方 公里, 总人口 245.6 万人。淮南矿产资源丰富, 煤炭 远景储量 444 亿 $\mathrm{t}$, 探明储量 153 亿 $\mathrm{t}$, 占华东地区 $32 \%$, 煤层气储量 5928 亿 $\mathrm{m}^{3}$ 。煤炭资源开采形成 “三废一沉”，每年煤炭开发和发电留下的煤研石和 粉煤灰高达 500 多万 $\mathrm{t}$, 占用耕地约 $4467 \mathrm{hm}^{2}$, 因采煤 造成塌陷 $10000 \mathrm{hm}^{2}$, 造成许多村庄和建筑物被废弃, 如今正以每年约 $347 \mathrm{hm}^{2}$ 的速度发展 ${ }^{[13]}$, 对淮南市 生态环境造成重大影响。

\section{2 生态承载力计算}

为综合考虑社会经济系统对生态承载力的影 响, 计算中引人社会经济系统发展指数 ${ }^{[14]}$ 进行生态 承载力的修正。模型计算公式为:

$$
F=X \times Y \times Z
$$

式中, $F$ 为社会经济系统发展指数, $X$ 为技术指数, 用 高新技术产业产值占工业总产值比重表示; $Y$ 为人 力资源指数, 用劳动力资源占总人口比重表示; $Z$ 为 经济能力指数, 用研究年与前一年的国内生产总值 比值表示。

$$
E C=\left(\sum_{i=1}^{n} A_{i} \times E Q_{i} \times Y_{i}\right) \times \mathrm{e}^{F} / N
$$

式中, $E C$ 为人均生态承载力, $A_{i}$ 为不同类型生态生 产性土地面积, $E Q_{i}$ 为均衡因子; $Y_{i}$ 为不同类型生态 生产性土地产量调整系数, 即产量因子; $F$ 为社会经 济系统发展指数; $N$ 为总人口数。

\section{3 基础数据处理}

以 1987、2000、2009、2012 年 4 期 Landsat TM 遥 感影像 (分辨率为 $30 \mathrm{~m}$ ) 为数据源, 依据生态足迹模 型的生物生产土地分类, 将以上 4 期遥感影像划分 为 6 种土地利用类型: 耕地、林地、水域、建筑用地、 草地和未利用地, 利用遥感影像处理软件 ENVI4. 8 对遥感影像进行坐标转换、几何校正, 通过人机交 互解译获得 4 期比例尺为 1:10 万的淮南市土地利用 类型图。通过 GPS 进行了野外抽样验证, 4 期土地 利用数据分类总体精度可达 $86.5 \%$ 。利用 GIS 空间 叠加分析获得淮南市 1987- 2000 年、2000- 2009 年、2009-2012 年 3 个时段的土地利用转移矩阵。 社会经济系统发展指数相关数据来源于《淮南市统 计年鉴》及淮南市政府工作报告, 以淮南市域为统计 单元。

\section{2 结果与讨论}

\section{1 生态承载力时空变化}

如图 1 所示, 1987-2012 年,淮南市人均生态承 载力总体呈现缓慢降低后略微升高的趋势。其中, 1987 - 2009 年, 淮南市人均生态承载力从 $0.65 \mathrm{hm}^{2}$ 下 降到 $0.49 \mathrm{hm}^{2}$, 年均下降 $1.36 \% ; 2012$ 年, 淮南市人均 生态承载力升高到 $0.51 \mathrm{hm}^{2}$ 。究其原因,一方面土地 利用变化显著, 1987-2012 年, 淮南市建筑用地增加 $13.93 \%$, 水域增加 $14.55 \%$, 林地降低 $19.68 \%$, 耕地 降低 $5.20 \%$, 耕地、水体、建筑用地、林地是淮南市土 地利用变化的核心类型, 矿区煤炭开采造成塌陷区 增加,形成大面积的积水塌陷区是淮南市水域面积 扩大的主要原因, 城镇人口和矿业经济快速增长则 
促使建筑用地的增长, 相关研究也有较一致的结 论 ${ }^{[15]}$ 。另一方面, 技术指数不断提高, 人力资源指 数略有下降, 经济能力指数曲折变化下略有提高, 在 三者的作用下,淮南市社会经济系统发展指数呈现 不断提高的趋势(表 1)。由公式(2)可以看出, 当社 会经济系统发展指数大于 0 时, 对生态承载力有强 烈的正反馈效应, 虽然生态承载力 (原始值) 不断降 低,但社会经济系统发展指数对生态承载力的提升 效应不断加强, 2009 年人均生态承载力从下降转变 为增长, 这正是社会经济系统发展指数正反馈的结 果。2009-2012 年,淮南市社会经济系统发展指数 年均增长率达到 1.42\%,而 1987-2009 年社会经济 系统发展指数年均增长率仅 $0.40 \%$, 因此, 2009 年淮 南市人均生态承载力的提高可以认为是经济效益、
科技水平的促进作用引起的。

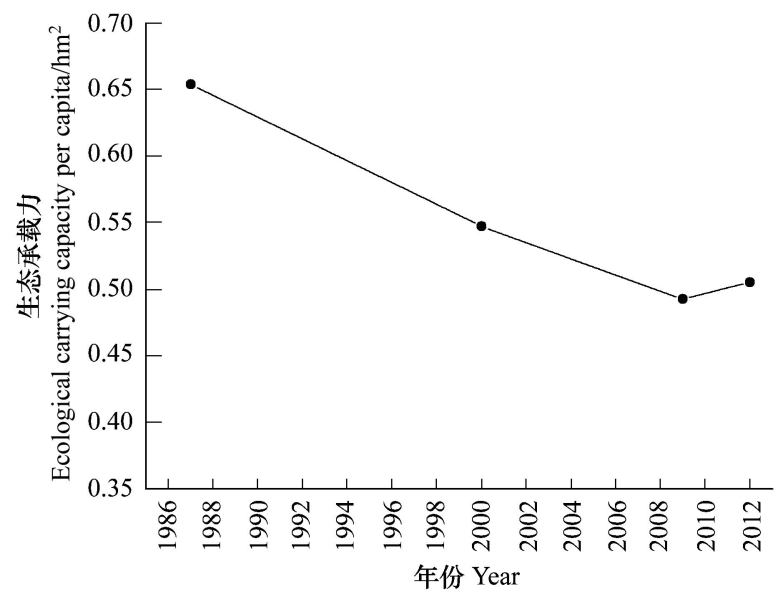

图 1 淮南市 $1987-2012$ 年人均生态承载力

Fig1 Ecological carrying capacity per capita in Huainan during 1987-2012

表 1 社会经济系统发展指数

Table 1 Social-economy system development index

\begin{tabular}{ccccc}
\hline $\begin{array}{c}\text { 年份 } \\
\text { Year }\end{array}$ & $\begin{array}{c}\text { 技术指数 } \\
\text { Technology index }\end{array}$ & $\begin{array}{c}\text { 人力资源指数 } \\
\text { Human resources index }\end{array}$ & $\begin{array}{c}\text { 经济能力指数 } \\
\text { Economy capacity index }\end{array}$ & $\begin{array}{c}\text { 社会经济系统发展指数 } \\
\text { social-economy system development index }\end{array}$ \\
\hline 1987 & 0.07 & 0.60 & 1.09 & 1.07 \\
2000 & 0.14 & 0.61 & 1.12 & 1.10 \\
2009 & 0.24 & 0.55 & 1.10 & 1.21 \\
2012 & 0.29 & 0.59 & 1.05 & \\
\hline
\end{tabular}

利用 4 期土地利用图中每个图斑包含的土地类 型及其对应的均衡因子和产量因子属性计算生态承 载力 (绝对值) ${ }^{[16]}$, 可以反映土地利用类型不同所致 的生态承载力差异，即生成 4 期淮南市生态承载力 (绝对值) 空间分布图 (图 2)。可以看出, 19872012 年, 淮南市生态承载力总体呈现显著的下降趋 势, 尤其 2000-2009 年变化最为明显。淮南市生态 承载力空间分异十分显著, 东南部田家庵区和谢家 集区生态承载力总体最高,连片分布,但 4 个时期内 略有下降,总体格局变化不大; 北部潘集区生态承载 力总体较高, 但由于景观破碎化较大导致区域生态 承载力差异显著, 2009-2012 年,该区域生态承载力 略有提高, 景观一体化加强,促进生态承载力空间整 体性加强; 西部风台县生态承载力总体较低, 总体格 局变化不大。总体而言, 淮南市生态承载力时空差 异显著,总体呈现东南和北部高、西部低的格局,而 且区域破碎化加剧的趋势。究其原因, 主要是淮南 市土地利用变化造成的, 矿区占用大量耕地以及积 水塌陷区的形成,进而导致生态承载力的下降和空
间格局分异。

2.2 不同类型用地的生态承载力变化分析

淮南市各类土地生态承载力占区域生态承载力 的比例差异显著,而且随着时间变化各类土地生态 承载力也存在明显的变化 (图 3)。可以看出, 耕地 生态承载力比例最高, 但下降幅度较高, 从 $79 \%$ 下降 到 $64 \%$, 建筑用地生态承载力比例增长较快, 从 $19 \%$ 到 $35 \%$, 水域生态承载力比例增长幅度最大, 从 $0.6 \%$ 到 $1.3 \%$, 林地、草地和未利用地生态承载力比 例变化不大,均小于 $1 \%$ 。淮南市土地利用改变直接 导致不同类型用地的生态承载力变化,耕地面积降 低,建筑用地、水域面积增长是淮南市土地利用变化 的整体特征,范忻等人研究成果表明淮南水体和建 筑用地扩张迅速,耕地面积以年均 $1.09 \%$ 的速度减 少 ${ }^{[15]}$, 这与本研究的结果非常一致。考虑到耕地和 建筑用地生态承载力的均衡因子最大, 水域生态承 载力的均衡因子较小,开展塌陷区整治,将塌陷区形 成的水域转换成耕地或建设用地,将是提高淮南市 生态承载力的最有效途径之一。 

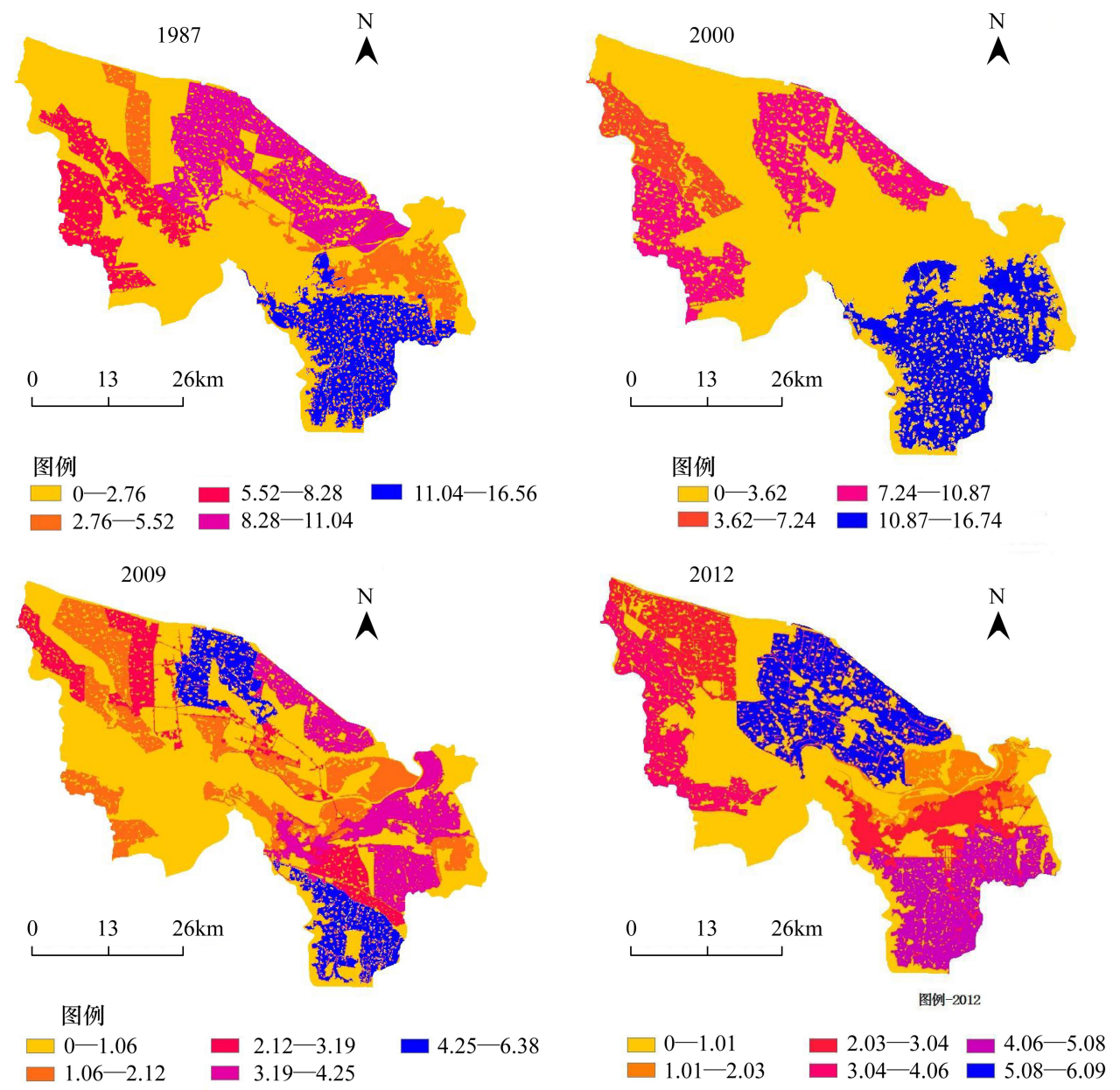

图 2 淮南市生态承载力 ( 绝对值) 空间分布

Fig.2 Spatial distribution of ecological capacity in Huainan

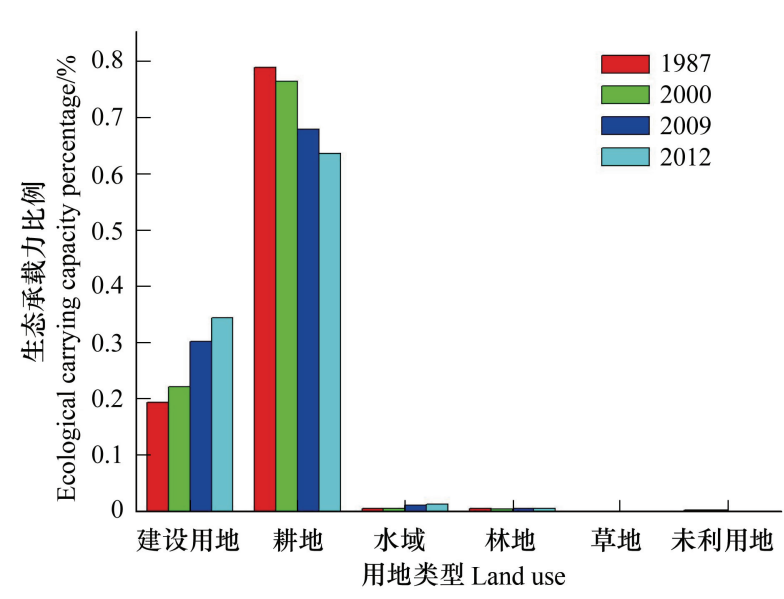

图 3 淮南市各类土地生态承载力变化

Fig. 3 The change of different land ecological capacity in Huainan

根据 4 期土地利用图，运用 GIS 的空间分析功 能, 获得淮南市 3 个时段的各类土地利用转移矩阵 (表 2一表 4)。可以看出,三期土地利用变化中耕地
转出量和转人量均最大, 占总转出量的 $51.40 \%$, 占 总转人量的 $40.53 \%$, 属于用地面积减少型, 主要转 移对象是建筑用地、水域和林地, 分别占耕地总转出 量的 $67.87 \% 、 28.52 \%$ 和 $3.61 \%$, 呈波动性变化; 建筑 用地变化仅次于耕地, 占总转出量的 $33.15 \%$, 占总 转人量的 $38.26 \%$, 属于用地面积增长型, 其中转人 量 $91.18 \%$ 来自于耕地; 水域变化排名第三, 占总转 出量的 $12.20 \%$, 占总转人量的 $18.71 \%$, 属于用地面 积增长型, 其中转入量主要来自于耕地和建筑用地, 分别占 $78.35 \%$ 和 $20.68 \%$; 林地以转出为主, 用地面 积略有减少; 草地、未利用地变化不大。总体而言, 淮南市土地利用转移以耕地、建筑用地为主, 水域对 土地利用格局的影响日益增强。

\section{3 结论与展望}

经济科技发展对生态承载力有一定的提升效 益, 本文研究结果进一步论证了这一结论。淮南市 
表 2 淮南市 $1987-2000$ 年土地利用转移矩阵 $/ \mathrm{hm}^{2}$

Table 2 The transfer matrix of land use in Huainan during 1987-2000

\begin{tabular}{lcccccc}
\hline $\begin{array}{l}\text { 用地类型 } \\
\text { Land use Type }\end{array}$ & $\begin{array}{c}\text { 耕地 } \\
\text { Farmland }\end{array}$ & $\begin{array}{c}\text { 林地 } \\
\text { Forest }\end{array}$ & $\begin{array}{c}\text { 水域 } \\
\text { Water Area }\end{array}$ & $\begin{array}{c}\text { 建筑用地 } \\
\text { Built-up Area }\end{array}$ & $\begin{array}{c}\text { 未利用地 } \\
\text { Unused Land }\end{array}$ & $\begin{array}{c}\text { 草地 } \\
\text { Pasture }\end{array}$ \\
\hline 耕地 Farmland & 1500.90 & 15.94 & 49.77 & 110.57 & 20.22 & 0 \\
林地 Forest & 1.74 & 42.09 & 0.17 & 1.15 & 0 & 0 \\
水域 Water Area & 73.39 & 0.47 & 228.12 & 22.08 & 0 & 0 \\
建筑用地 Built-up Area & 196.90 & 3.69 & 12.06 & 289.43 & 0 & 0 \\
未利用地 Unused Land & 0 & 0 & 0 & 0 & 0 & 0 \\
草地 Pasture & 0.12 & 0 & 0 & 0 & 0 & 0 \\
\hline
\end{tabular}

表 3 淮南市 $2000-2009$ 年土地利用转移矩阵 $/ \mathrm{hm}^{2}$

Table 3 The transfer matrix of land use in Huainan during 2000-2009

\begin{tabular}{|c|c|c|c|c|c|c|}
\hline 用地类型 ～ & 耕地 & 林地 & 水域 & 建筑用地 & 未利用地 & 草地 \\
\hline Land use Type & Farmland & Forest & Water Area & Built-up Area & Unused Land & Pasture \\
\hline 耕地 Farmland & 1471.52 & 5.02 & 43.69 & 190.39 & 0 & 0 \\
\hline 林地 Forest & 19.01 & 39.66 & 2.66 & 4.11 & 0 & 0 \\
\hline 水域 Water Area & 84.30 & 0.67 & 240.31 & 13.28 & 0 & 0 \\
\hline 建筑用地 Built-up Area & 159.87 & 0.89 & 13.18 & 294.15 & 0 & 0 \\
\hline 未利用地 Unused Land & 0.13 & 0 & 0 & 0 & 0 & 0 \\
\hline 草地 Pasture & 1.18 & 0 & 0 & 0 & 0 & 0 \\
\hline
\end{tabular}

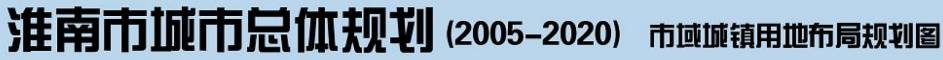

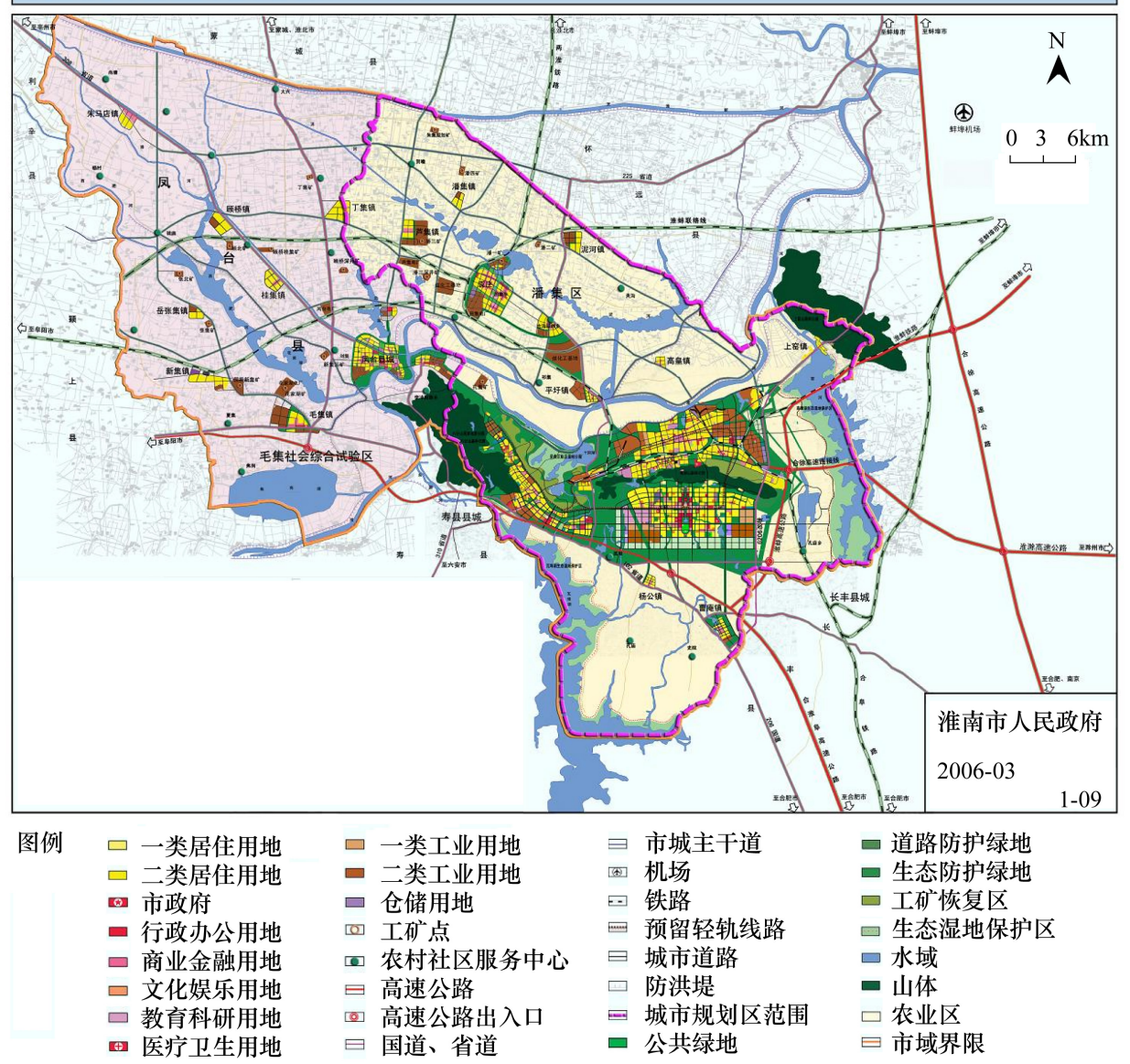

图 4 淮南市城市用地发展方向

Fig.4 Development direction of urban land in Huainan city 
表 4 淮南市 $2009-2012$ 年土地利用转移矩阵 $/ \mathrm{hm}^{2}$

Table 4 The transfer matrix of land use in Huainan during 2009-2012

\begin{tabular}{lcccccc}
\hline $\begin{array}{l}\text { 用地类型 } \\
\text { Land use Type }\end{array}$ & $\begin{array}{c}\text { 耕地 } \\
\text { Farmland }\end{array}$ & $\begin{array}{c}\text { 林地 } \\
\text { Forest }\end{array}$ & $\begin{array}{c}\text { 水域 } \\
\text { Water Area }\end{array}$ & $\begin{array}{c}\text { 建筑用地 } \\
\text { Built-up Area }\end{array}$ & $\begin{array}{c}\text { 未利用地 } \\
\text { Unused Land }\end{array}$ & $\begin{array}{c}\text { 草地 } \\
\text { Pasture }\end{array}$ \\
\hline 耕地 Farmland & 1456.06 & 11.59 & 60.35 & 160.50 & 0 & 0.88 \\
林地 Forest & 8.81 & 40.07 & 0.97 & 1.19 & 0 & 0 \\
水域 Water Area & 76.65 & 1.74 & 233.78 & 26.48 & 0 & 0.39 \\
建筑用地 Built-up Area & 200.79 & 12.05 & 12.08 & 279.43 & 0 & 0 \\
未利用地 Unused Land & 0 & 0 & 0 & 0 & 0 & 0 \\
草地 Pasture & 0 & 0 & 0 & 0 & 0 \\
\hline
\end{tabular}

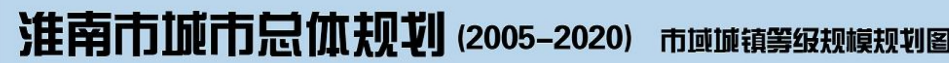

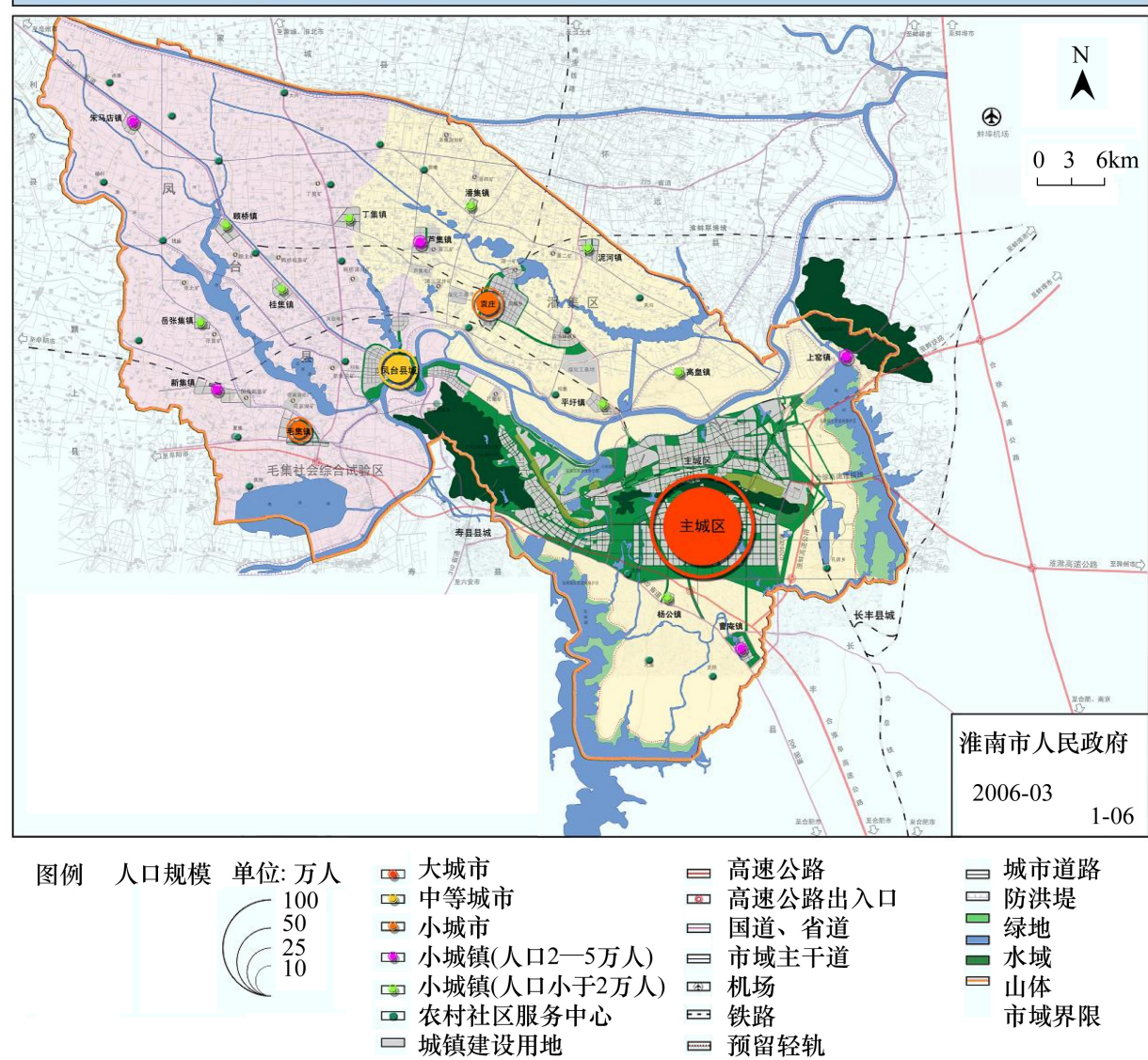

图 5 淮南市城镇空间结构

Fig.5 Urban spatial structure in Huainan city

作为典型的煤炭资源型城市, 矿业经济对于土地利 用的影响直接促使生态承载力时空格局的变化,开 展塌陷区整治,将塌陷区形成的水域转换成耕地或 建设用地,将是提高淮南市生态承载力的最有效途 径之一。遥感和 GIS 技术的应用为可视化展示生态 承载力时空变化特征提供了技术保证,弥补了传统 生态承载力计算过多依靠社会经济统计数据的缺 陷。然而,运用高分辨率遥感影像 ( 分辨率 $10 \mathrm{~m}$ 以
下) 精确判定土地利用类型,运用方格网分析土地利 用,针对不同类型塌陷区 (稳沉区和非稳沉区) 开展 生态承载力研究具有重要意义。此外,本研究成果 可为淮南市总体规划提供依据, 如生态承载力可以 作为城市用地发展方向选择的指标,本文研究表明 舜耕山以南、城市东南方生态承载力较高, 建议淮南 市主城区主要向南发展,在舜耕山以南形成新城区, 西部城区和北部城区向东南方向发展,这与淮南市 
总体规划确定的城市用地发展方向是一致的 (图 4); 另外,生态承载力可以判断城市空间结构选择的 合理性,淮南市总体规划确定 “一主两副三区” 的空 间发展结构: “一主” :指淮南主城区; “两副”: 2 个副 中心城市, 即潘集区驻地, 凤台县城; “三区” : 即南部 城市发展区、北部城镇发展区和西部城镇发展区 (图 5 ), 本研究得出潘集区生态承载力总体较高,但由于 景观破碎化较大导致区域生态承载力差异显著, 凤 台县生态承载力总体较低, 总体格局变化不大, 建议 2 个副中心城市在发展指引方面应该依据生态承载 力状况给出不同的发展战略。因此,运用生态承载 力分析矿业城市用地适宜性、空间布局合理性、项目 选址等内容, 加强生态承载力在城乡规划中的应用, 将是矿业城市生态承载力研究的重要方向之一。

致谢: 中国科学院沈阳应用生态研究所杨健研究员 对本文写作给予帮助,特此致谢。

\section{References :}

[ 1 ] Fan J, Sun W, Fu X F. Problems, reasons and strategies for sustainable development of mining cities in China. Journal of Natural Resources, 2005, 20(1): 68-77.

[ 2 ] Zhang Y J. Comparison study on types and status of mining cities. Human Geography, 2005, (6) : 83-87.

[ 3 ] IUCN, UNEP, WWF. Caring for the earth: a strategy for sustainable living. Switzerland: Earthscan Ltd., 2009.

[ 4] Arrow K, Bolin B, Costanza R. Economic growth, carrying capacity, and the environment. Ecological Application, 1995, 6 (1) : 13-15.

[ 5 ] Zou D C. On the issue of sustainable development of resource oriented (mining) cities. Planners, 2006, 22(4) : 7-8.

[ 6 ] Wackernagel M, Onisto L, Bello P, Linares A C, Falfán I S L, García J M, Guerrero A I S, Guerrero M G S. National natural capital accounting with the ecological footprint concep. Ecological Economics, 1999, 29(3) : 375-390.

[ 7 ] Yue D X, Xu X F, Li Z Z, Hui C, Li W L, Yang H Q, Ge J P. Spatiotemporal analysis of ecological footprint and biological capacity of Gansu, China 1991-2015: Down from the environment cliff. Ecological Economics, 2006, 58 (2) : 393-406.

[ 8 ] Niccolucci V, Tiezzi E, Pulselli F M, Capineri C. Biocapacity vs Ecological Footprint of world regions: A geopolitical interpretation. Ecological Indicators, 2012, 16: 23-30.

[ 9 ] David B, Bernadette O, Richard M. Comparison of energy flow accounting, energy flow metabolism ratio analysis and ecological footprinting as tools for measuring urban sustainability: A case- study of an Irish city-region. Ecological Economics, 2012, 83: 97-107.

[10] Zhao J J, Li X S, Guo C Y, Pei L, Du X, Wu B F. Evaluation of Yiwu ecological carrying capacity based on ecological footprint analysis approach. City Planning Review, 2010, 34(11) : 40-46.

[11] Yue D X, DU J, Liu J Y, Guo J J, Zhang J J, Ma J H. Spatiotemporal analysis of ecological carrying capacity in Jinghe watershed based on remote sensing and transfer matrix. Acta Ecologica Sinica, 2011, 31(9) : 2550-2558.

[12] Gu K K, Liu J S, Dou J X. The research about ecological carrying capacity of mining cities in central Liaoning. Journal of Natural Resources, 2008, 23(1) : 87-94.

[13] Liu J L. An analysis of the current situation for resource-based cities and the counter measures for its sustainable development. Journal of Jixi University, 2008, 8(4) : 41-43.

[14] Gu K K, Liu J S. Study on the ecological carrying capacity in mining city based on the modified model of ecological footprint. Journal of China Coal Society, 2008, 33(11) : 1314-1318.

[15] Fan X, Wang Y J, Zhang S J. Remote sensed monitoring of land use change in Huainan mining area and its driving forces analysis. Mining Research and Development, 2012, 32(4): 81-84.

[16] Yue D X, Ma J H, Gong J, Xiong Y C, Song Y J. Quantitative estimation and spatial pattern analysis of ecological carrying capacity in Northwestern China based on GIS. Journal of Lanzhou University: Natural Sciences, 2009, 45(6): 68-75.

\section{参考文献:}

[1] 㚞杰, 孙威, 傅小锋. 我国矿业城市持续发展的问题、成因与 策略. 自然资源学报, 2005, 20(1)：68-77.

[2] 张耀军. 矿业城市类型及发展现状比较研究. 人文地理, 2005, (6) : 83-87.

[ 5 ] 邹德慈. 资源型 (矿业) 城市的可持续发展问题. 规划师, 2006, 22(4): 7-8.

[10］赵晶晶, 李晓松, 郭重阳, 裴亮, 杜金金, 吴炳方. 基于生态足 迹分析的义乌市生态承载力评价. 城市规划, 2010, 34(11): 40-46.

[11] 岳东霞, 杜军, 刘俊艳, 郭建军, 张佳静, 马金辉. 基于 RS 和 转移矩阵的泾河流域生态承载力时空动态评价. 生态学报, 2011, 31(9) : 2550-2558.

[12] 顾康康, 刘景双, 窦晶金金. 辽中地区矿业城市生态承载力研 究. 自然资源学报, 2008, 23(1) : 87-94.

[13] 刘家乐. 资源型城市的现状分析及实现可持续发展的对 策一以安徽省淮南市为例. 鸡西大学学报, 2008, 8(4): 41- 43 .

[14] 顾康康, 刘景双. 基于生态足迹修正模型的矿业城市生态承 载力研究. 煤炭学报, 2008, 33(11): 1314-1318.

[15] 范忻, 汪云甲, 张书建. 淮南矿区土地利用变化遥感监测及驱 动力分析. 矿业研究与开发, 2012, 32(4)：81-84.

[16] 岳东霞, 马金辉, 巩杰, 熊友才 宋雅杰. 中国西北地区基于 GIS 的生态承载力定量评价与空间格局. 兰州大学学报: 自然 科学版, 2009, 45(6): 68-75. 